\title{
Is Unilateral Conversion The Best Solution?
}

\author{
Mohamed Azam Mohamed Adil*
}

The issue of unilateral conversion of minors has once again generated widespread uproar in Malaysia when the Federal Court unanimously decided, in the case of Indira Ghandi on 29 January 2018, that both the parents' consent was required in determining the faith of minors.

In Malaysia, Article 12 (4) of the Federal Constitution provides that "For the purposes of Clause (3) the religion of a person under the age of eighteen years shall be decided by his parent or guardian." The Federal Court held, in this case, that the word 'parent' must be understood in the plural form, denoting both 'parents', based on Schedule Eleven of the Federal Constitution and sections 5 and 11 of the Guardianship Act 1961. This decision marked a departure from the previous Federal Court judgement in Subashini (2007) in which 'parent' was defined as one of the parents. The Federal Court in the Indira Ghandi case also rejected the argument put forth by some parties that the decision in the case of Susie Teoh (1990), who voluntarily converted to Islam at the age of 16, had a bearing on the interpretation of the word 'parent' as singular or plural.

It may be useful to refer, in this regard, to some points discussed in two of the International Institute of Advanced Islamic Studies (IAIS) Malaysia's policy papers, "Conversion in Malaysia: Issues and Reform Proposals" (2012) and its Malay-language version, "Penukaran Agama Kanak-Kanak - Isu dan Cadangan" (2016 \& 2017), which updated and enhanced the previous edition.

Muslim jurists have held that when both parents convert to Islam, their underage children automatically become Muslims. Problems arise if one of the parties has converted to Islam and the other remains a non-Muslim, leading to an interesting jurisprudential debate. Jurists have held different opinions in such a scenario. The majority views in the Hanafi, Shafi'i and Hanbali schools revolve around whether the convert was the mother or the father. Things are more straightforward in the Maliki school, which stipulates that the child's religion follow that of the father. Thus, if the father converts, so will the child. The argument behind this Maliki ruling is that the identity and lineage of descent are through the father. Even so, there seems to be no final and authoritative view on this matter, especially since no clear-cut Quranic verses address it. Nor have the jurists reached any consensus on the question of whether a child can embrace any religion, including Islam. 
Many scholars are of the view that children can embrace Islam, based on the precedents of many close companions of the Prophet Muhammad who converted to Islam during their childhood. Among them were 'Ali bin Abi Talib, Zubayr bin al-Awwam, Abdullah ibn Umar and Asma' binti Abu Bakr. Imam Abu Hanifah and his disciple, Muhammad ibn Hassan al-Syaibani, are of the view that children that have attained mumayyiz (prudence) can legitimately convert to Islam - or, for that matter, opt for apostasy. However, Abu Yusuf is of the view that the child's decision is legitimate only when he converts to Islam, and invalid in the case of apostasy. Zufar ibn Hudhayl, another disciple of Imam Abu Hanifah, views that a child can neither convert to Islam nor leave Islam if he or she has not reached puberty.

Several important points can be drawn from the popular hadith "Every child is born in 'fitrah' (natural state). His parents are the ones who will determine whether he is a Jew or a Christian until he is able to accept or reject it." First, it is implied that a child cannot determine his religion. Second, it is also implied that a child's disposition is clear of sin and cannot be held responsible for his religious status or other religious requirements. Additionally, this hadith also mentions 'parents' in the plural.

What is most important throughout this whole issue, however, is that the welfare of the child should come above all else. What is happening now in Malaysia is that there have been cases where a father or mother embraces Islam and later converts their child to Islam even before the court resolves the issue of custody. This scenario will undoubtedly lead to further problems. Similarly, an automatic decision to keep the child in his original religion following his nonMuslim parent will also lead to future problems, for instance when the Muslim parent gains custody and wishes to enrol the child for Islamic religious education. Therefore, the determination of a child's religion should take into account the custodianship of the child. Solving this predicament would require cooperation by all parties, especially parents, guardians and the authorities, to prioritise the welfare of the child. This cooperation can be actualised through a mediation process which involves a third party that will facilitate both parents towards reaching a compromise regarding the religious status of their child, for the sake of the children's welfare.

For that reason, IAIS Malaysia proposed several policy reforms in its above mentioned policy papers relating to conversions in interfaith marriages. Among the recommendations were, firstly, to ensure that the issue of conversion does not get in the way of ensuring the child's welfare and the ensuing custodial responsibilities by the disputing parents. Secondly, to establish a particular branch of the judiciary with mixed jurisdiction where both shariah and civil law judges can sit and adjudicate cases of conversion and religious identity of 
children. Thirdly, to set up a judicial committee of the Conference of Malay Rulers with a mixed composition of Muslims and non-Muslims. The former can be the majority, and female members shall be included.

\section{Notes}

* Mohamed Azam Mohamed Adil Deputy CEO, International Institute of Advanced Islamic Studies (IAIS) Malaysia, Jalan Elmu off Jalan Universiti, 59100 Kuala Lumpur/Associate Professor, Academy of Contemporary Islamic Studies (ACIS), Universiti Teknologi MARA Selangor, 40450 Shah Alam, Selangor (mazamadil@iais.org.my/mazamadil@hotmail.com). 